\title{
Bacterial Disinfection Using Polymer Based Hybrids
}

\author{
ANAM Safri ${ }^{a,{ }^{*}}$, JUNAID Ur Rehman ${ }^{b}$, SAIMA Shabbir ${ }^{c}$ \\ SYED Wilayat Hussain ${ }^{d}$
}
Department of Materials Science and Engineering, Institute of Space Technology, Islamabad 44000, Pakistan

aanam1206@yahoo.com, bjunaid@ist.edu.pk, cdrsaimashabbir@gmail.com, dwilayat.hussain@ist.edu.pk

Keywords: Water disinfection, Polymer, Hybrid.

\begin{abstract}
Sol-gel chemistry was adeptly exploited to fabricate polymer based hybrids for solar disinfection to render clean drinking water. The present research study was carried out by inclusion of different proportions of titania $(2.5$ and $7.5 \mathrm{wt}$. \%) that covalently cross-linked with the polymer matrix. In addition to morphological studies, the optical band gap and wavelength absorbed was investigated through UV-Vis absorption spectra. Moreover, the efficacy of photocatalytic antimicrobial activity of polymer based hybrids was evaluated using source water with controlled amount of total coliform that causes waterborne diseases. This research provided a green synthesis approach for water disinfection along with no disinfection byproduct formation, thus, rendering energy efficient and cost-effective water disinfection.
\end{abstract}

\section{Introduction}

On the basis of adsorption phenomenon for the removal of pollutants from contaminated water, the design and development of polymer based hybrids have been emerging as an easy and cost effective approach for water disinfection [1]. Although, the traditional methods effectively remove pollutants including heavy metals [2], dyes [3] and organic pollutants [4], but these methods still suffer costly regeneration and selective removal of organic chemicals [5]. Meanwhile, more efficient polymer based adsorbents are being prepared for effective water disinfection [6-8]. Therefore, these advanced materials are substituting the traditional methods to attain potable water due to their large surface area, better thermal and mechanical profile, and controlled characteristics such as pore size and tunable surface chemistry $[9,10]$. However, their efficacy can be further maximized by tuning the properties for a large-scale application.

The removal of organic pollutants to attain contaminant free drinking water is possible through adsorption technology, while there is an accessibility of a wide range of adsorbents. Literature reports efficient removal of phenolic wastes through polymer based adsorbents along with recovery of reusable raw materials [11-13]. Likewise, traces of noxious wastes from industries entering into the drinking water supplies has been a serious concern in the past few decades that is overcome with the use of these polymer adsorbents [14]. However, not all polymeric adsorbents adsorb all the pollutants, but their adsorption capacity can be enhanced to remove certain bacteria which cause waterborne diseases along with the removal of organic pollutants to attain potable water [15]. The utilization of nanoparticles can be helpful for this purpose due to their large surface area and higher contribution [16]. Previously, metal oxides nanoparticles including titania, aluminum and iron oxides are reported to have specific adsorption affinity toward charged pollutants along with decontamination of disinfection byproducts in drinking water $[2,17,18]$. A combination of polymer and nanoparticles can be used due to diverse physio-chemical properties that are appropriate for water disinfection. Therefore, the synthesis of hybrid made from dispersed metal oxide nanoparticles and polymer matrix can be an efficient route to obtain a water disinfectant.

In this research, we have synthesized a polymer based hybrid with a block copolymer and titania nanoparticles for deep removal of organic pollutants from contaminated water. The incorporated titania nanoparticles through photocatalysis produces reactive oxide species and hydroxyl radicals responsible for killing the bacteria [19]. Meanwhile, the polymer support functions as a porous 
adsorbent [20, 21]. Ultimately, the as obtained polymer based hybrids were tested against contaminated water for the removal of total coliform through an MPN (most probable number) method.

\section{Materials and Methodology}

An anhydride grafted triblock copolymer of styrene-ethylene-butylene was used as a polymer matrix. For in-situ so-gel synthesis of polymer based hybrid, titanium isopropoxide (TTIP) was reacted with water to imbed titania in polymer. A small amount of silane coupling agent was added to the reaction mixture to form a linkage between titania and the polymer matrix. The reaction mixture was left to stir at room temperature for $24 \mathrm{~h}$. Ultimately, the mixture was poured onto Teflon Petri dishes to obtain polymer based hybrids. Two hybrids containing $2.5 \mathrm{wt}$ \% and 7.5 wt. $\%$ of titania were obtained to test as water disinfection efficiency.

\section{Characterization Techniques}

Morphology of polymer based hybrids was examined through FESEM (field emission scanning electron microscope) using MIRA3 TESCAN, the polymer based hybrids were sputter coated using sputter coater machine (Q150 QUORUM) with graphite with an average thickness of 10-15 $\mu \mathrm{m}$ before examination under FESEM. UV-Vis spectroscopy was performed with Cary 5000UV-VisNIR Spectrophotometer. Disinfection studies were performed at Pakistan Council of Research in Water Resources (PCRWR) through MPN/100 ml method.

\section{Results and Discussion}

Morphological and Optical Analysis: Micrograph of polymer based hybrids is shown in Fig. 1. Well dispersed titania nanoparticles in the polymer matrix were observed that is accountable for maximum UV absorption. Therefore, to confirm the maximum wavelength absorbed by the polymer based hybrids, UV-Vis spectra of absorption against wavelength was obtained (Fig. 2 a). It was evaluated that the maximum wavelength absorbed was in the range of $320-400 \mathrm{~nm}$. While the Tauc plot (Fig. 2 b) was plotted to determine the optical band gap that was estimated to be $3.12 \mathrm{eV}$.

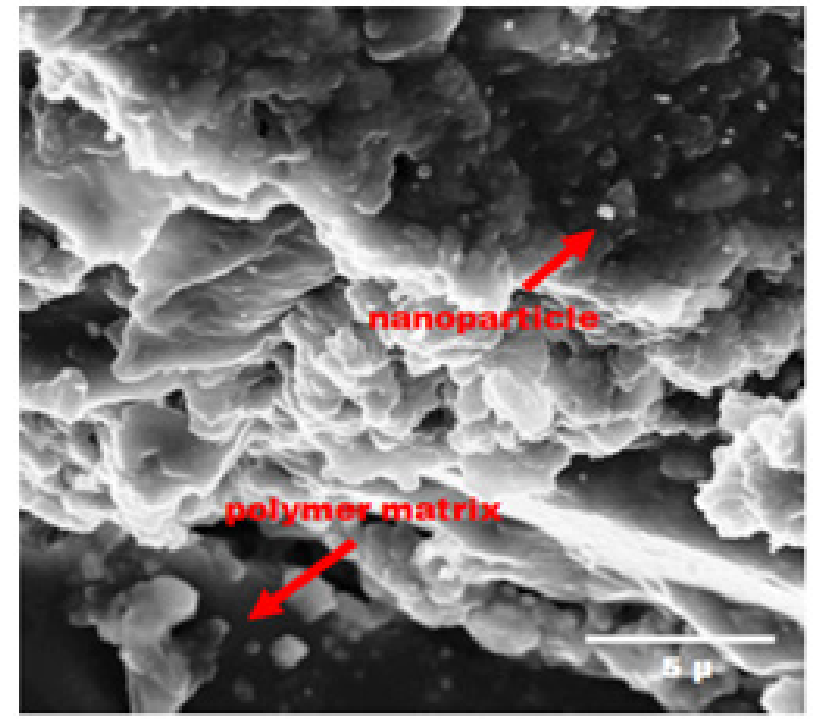

Fig. 1 FESEM image of polymer based hybrid. 


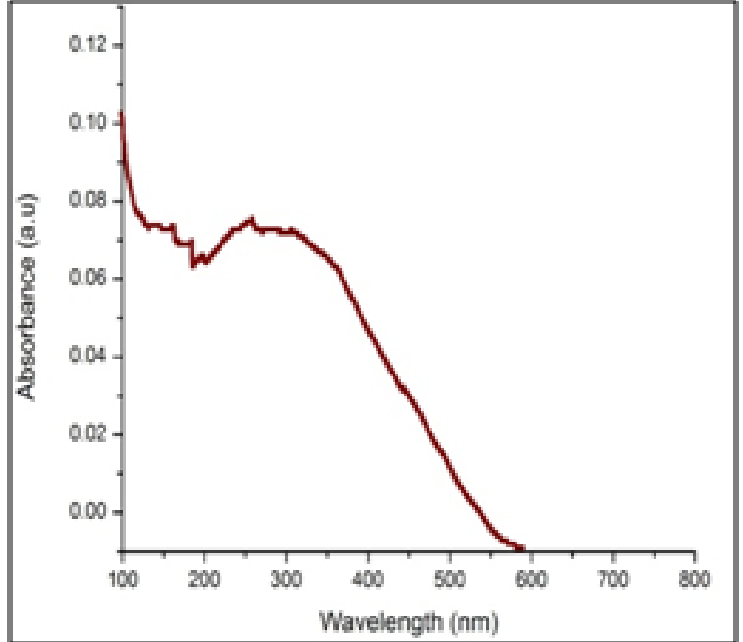

Fig. 2 (a) UV-Vis absorption spectra.

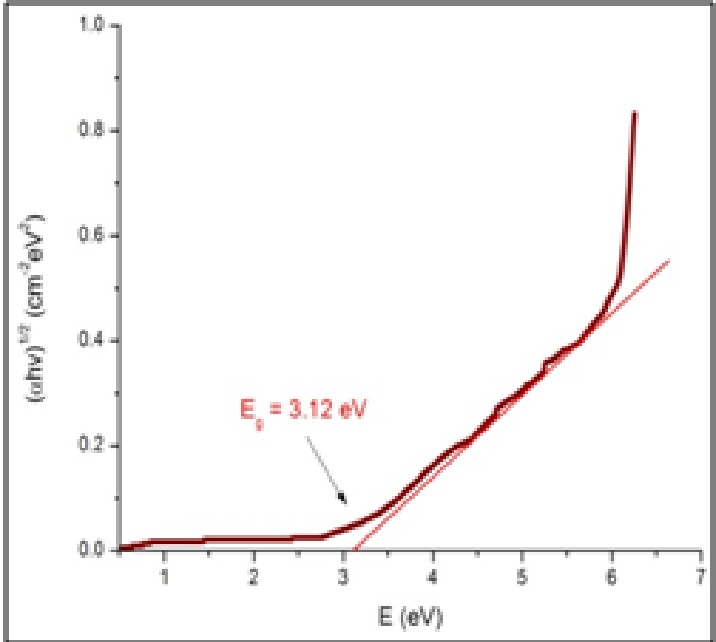

Fig. 2 (b) Tauc plot.

Water Disinfection Studies: Table 1 shows the disinfectant activity of the two polymer based hybrids after analysis through MPN/100ml method. The water disinfection activity was calculated by the percentage difference in initially present and remaining total coliform count after UV exposure for $3 \mathrm{~h}$ of contaminated water containing polymer based hybrids and different disinfectant activities for each sample were observed as shown in Fig. 3. It was found that the hybrid containing $2.5 \mathrm{wt} \%$ of titania in the polymer showed $50 \%$ reduction in total coliform while the hybrid containing $7.5 \mathrm{wt} \%$ of titania showed around $90 \%$ reduction in total coliform (also refer annex-1). The reason was based on the content of titania present in the polymer based hybrids, where more amount of titania caused generation of a larger number of reactive oxide species that caused killing of bacteria through photocatalysis [22, 23].

Table 1 Water disinfection activity after analysis through MPN/100ml method.

\begin{tabular}{ccc}
\hline Sample & $\begin{array}{c}\text { Total coliform count } \\
\text { (MPN/100ml) }\end{array}$ & $\begin{array}{c}\text { Percentage } \\
\text { reduction in total } \\
\text { coliform (\%) }\end{array}$ \\
\hline $\begin{array}{c}\text { Contaminated water (Reference) } \\
\text { Polymer based hybrid } \\
\text { with 2.5wt\% titania } \\
\begin{array}{c}\text { Polymer based hybrid } \\
\text { with 7.5wt\% titania }\end{array}\end{array}$ & 140 & - \\
\hline
\end{tabular}

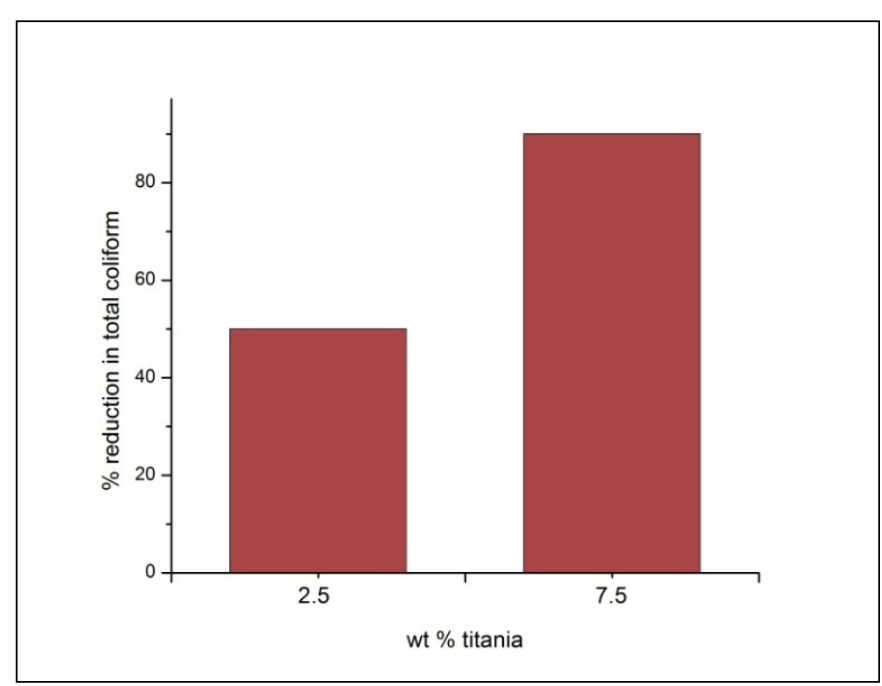

Fig. 3 Graph shows the disinfectant activity after analysis through MPN/100ml method. 


\section{Summary}

The findings through our research suggested that sol-gel technique was efficient method to fabricate polymer based hybrids. Moreover, polymer matrix provided immobilization of nanoparticles along with better dispersion. This approach can be considered as an environment friendly synthesis, since it eliminates post treatment removal. Furthermore, efficacy of disinfectants also increased with increased titania content, where up to $90 \%$ of reduction in total coliform was achieved with no reaction byproducts. Finally, the properties of these hybrids can be further tuned to achieve complete contaminant free drinking water. Thus, this research can provide an efficient and costeffective pathway to obtain potable water, especially in developing countries.

\section{Acknowledgement}

S. Shabbir is grateful to Higher Education Commission (HEC) of Pakistan for providing funds for this work under NRPU project No. 5851/Federal/NRPU/R\&D/HEC/2016. The authors are thankful to Pakistan Council of Research in Water Resources (PCRWR) for water disinfection tests.

\section{References}

[1] M.N. Rashed, Adsorption technique for the removal of organic pollutants from water and wastewater, Org. zollutants-monitoring, risk and treatment, pp. 167-194: InTech, 2013.

[2] F. Fu, and Q. Wang, Removal of heavy metal ions from wastewaters: a review, J. Envir. Manag., 92 (2011) 407-418.

[3] H. Gao, S. Zhao, X. Cheng, X. Wang, and L. Zheng, Removal of anionic azo dyes from aqueous solution using magnetic polymer multi-wall carbon nanotube nanocomposite as adsorbent, Chem. Engin. J., 223 (2013) 84-90.

[4] M. Otero, M. Zabkova, and A. E. Rodrigues, Comparative study of the adsorption of phenol and salicylic acid from aqueous solution onto nonionic polymeric resins, Separ. Puri. Technol., 45(2005) 86-95.

[5] B. Pan, B. Pan, W. Zhang, L. Lv, Q. Zhang, and S. Zheng, Development of polymeric and polymer-based hybrid adsorbents for pollutants removal from waters, Chem. Engin. J., 151(2009)19-29.

[6] S.Q. Memon, N. Memon, and A.R. Solangi, Sawdust: a green and economical sorbent for thallium removal, Chem. Engin. J., 140 (2008) 235-240.

[7] T.A. Johnson, N. Jain, H. Joshi, and S. Prasad, Agricultural and agro-processing wastes as low cost adsorbents for metal removal from wastewater: A review, J. Scien. Indust. Res., 67 (2008) 647-658.

[8] O. Hernandez-Ramirez, and S. M. Holmes, Novel and modified materials for wastewater treatment applications, J. Mater. Chem., 18 (2008) 2751-2761.

[9] P. Cornel, and H. Sontheimer, Sorption of dissolved organics from aqueous solution by polystyrene resins-I. Resin characterization and sorption equilibrium, Chem. Engin. Sci., 41 (1986) 1791-1800.

[10] R. Kunin, Polymeric adsorbents for treatment of waste effluents, Poly. Engin. \& Sci., 17 (1977) 58-62.

[11] X. Zeng, Y. Fan, G. Wu, C. Wang, and R. Shi, Enhanced adsorption of phenol from water by a novel polar post-crosslinked polymeric adsorbent, J. Hazard. Mater., 169 (2009) 1022-28.

[12] S.-H. Lin, and R.-S. Juang, Adsorption of phenol and its derivatives from water using synthetic resins and low-cost natural adsorbents: a review, J. Environ. Manag., 90 (2009) 1336-49. 
[13] M. Caetano, C. Valderrama, A. Farran, and J. L. Cortina, Phenol removal from aqueous solution by adsorption and ion exchange mechanisms onto polymeric resins, J. Coll. Interf. Sci., 338 (2009) 402-9.

[14] M. Barakat, New trends in removing heavy metals from industrial wastewater, Arab. J. Chem., 4 (2011) 361-77.

[15] I. Ali, New generation adsorbents for water treatment, Chem. Rev.s, 112 (2012) 5073-91.

[16] I. Pandová, "Zeolite as Nanomaterial for Water Treatment in a Production Exploitation, Key Engin. Mater., 756 (2017) 44-51.

[17] J. Bargar, G. Brown, and G. Parks, Surface complexation of $\mathrm{Pb}$ (II) at oxide-water interfaces: I. $\mathrm{XAFS}$ and bond-valence determination of mononuclear and polynuclear $\mathrm{Pb}$ (II) sorption products on aluminum oxides, Geochi. Cosmochi. Act., 61 (1997) 2617-37.

[18] J. Sawai, and T. Yoshikawa, Quantitative evaluation of antifungal activity of metallic oxide powders $(\mathrm{MgO}, \mathrm{CaO}$ and $\mathrm{ZnO})$ by an indirect conductimetric assay, J. Appl. Microbio., 96 (2004) 803-09.

[19] K. R. Reddy, M. Hassan, and V. G. Gomes, Hybrid nanostructures based on titanium dioxide for enhanced photocatalysis, Appl. Catal. A: General, 489 (2015) 1-16.

[20] C. Costa, and A. Rodrigues, Design of cyclic fixed-bed adsorption processes. Part I: Phenol adsorption on polymeric adsorbents, AICHE J., 31 (2985) 1645-54.

[21] A.G. Slater, and A. I. Cooper, Function-led design of new porous materials, Sci., 348 (2015) 6238 .

[22] U.I. Gaya, and A.H. Abdullah, Heterogeneous photocatalytic degradation of organic contaminants over titanium dioxide: a review of fundamentals, progress and problems, J. Photochemi. Photobiol. C: Photochemi. Rev., 9 (2008) 1-12.

[23] G. Kickelbick, The search of a homogeneously dispersed material - the art of handling the organic polymer/metal oxide interface, J. Sol-Gel Scie. Technol., 46 (2008) 281-90. 